\title{
Correction to: Transmission studies of the newly described apple chlorotic fruit spot viroid using a combined RT-qPCR and droplet digital PCR approach
}

\author{
Thomas Leichtfried $^{1} \cdot$ Helga Reisenzein ${ }^{1} \cdot$ Siegrid Steinkellner ${ }^{2}$ (I) $\cdot$ Richard A. Gottsberger $^{1}$
}

Published online: 30 August 2020

(c) The Author(s) 2020

\section{Correction to: Archives of Virology https://doi.org/10.1007/s00705-020-04704-5}

Authors would like to update the given name and family name of authors which were incorrect in the original version.

The original article has been corrected.

Open Access This article is licensed under a Creative Commons Attribution 4.0 International License, which permits use, sharing, adaptation, distribution and reproduction in any medium or format, as long as you give appropriate credit to the original author(s) and the source, provide a link to the Creative Commons licence, and indicate if changes were made. The images or other third party material in this article are included in the article's Creative Commons licence, unless indicated otherwise in a credit line to the material. If material is not included in the article's Creative Commons licence and your intended use is not permitted by statutory regulation or exceeds the permitted use, you will need to obtain permission directly from the copyright holder. To view a copy of this licence, visit http://creativecommons. org/licenses/by/4.0/.

The original article can be found online at https://doi.org/10.1007/ s00705-020-04704-5.

Siegrid Steinkellner

siegrid.steinkellner@boku.ac.at

1 Institute for Sustainable Plant Protection, Austrian Agency for Health and Food Safety, 1220 Vienna, Austria

2 Institute of Plant Protection, University of Natural Resources and Life Sciences, 3430 Tulln an der Donau, Austria 